\title{
Relationships between soil factors, Quercus robur health, Collybia fusipes root infection and Phytophthora presence
}

\author{
Cécile Camy, Claude Delatour, Benoît Marçais** \\ Unité de Pathologie Forestière, INRA, Centre de Nancy, 54280 Champenoux, France
}

(Received 22 March 2002; accepted 5 August 2002)

\begin{abstract}
About sixty oaks (Quercus robur), with different status of crown health, located in three plots in north eastern France were assessed for their degree of infection by $C$. fusipes. Baiting of Phytophthora spp. from soil was carried out at different seasons in a sub sample of these oaks. The variability of soil characteristics, such as depth to waterlogging signs and depth to a gravel layer limiting rooting was evaluated. Soil factors were tightly correlated. Infection induced by $C$. fusipes was significantly more severe in non-waterlogged conditions. In two plots Phytophthora spp. were present at the base of the majority of trees investigated. Success of Phytophthora isolation was significantly linked with the season. The crown health status deteriorates with increasing severity of infection by C. fusipes and with the depth to waterlogging. Conversely, Phytophthora was not correlated with crown health status.
\end{abstract}

Quercus / Collybia fusipes / root rot fungus / Phytophthora sp. / oak decline

Résumé - Relations entre les facteurs du sol, l'état du houppier de Quercus robur, les infections racinaires induites par Collybia fusipes et la présence de Phytophthora. Le niveau d'infection induit par Collybia fusipes a été évalué sur environ 60 chênes pédonculés $(Q u e r c u s$ robur) présentant différents états sanitaires, situés dans trois parcelles du nord-est de la France. Le piégeage des Phytophthora spp. présents dans le sol a été effectué sur un sous-échantillon de chênes à différentes saisons. La variabilité des facteurs du sol concernant la profondeur d'apparition des traces d'hydromorphie et la profondeur d'apparition d'un plancher de graviers limitant l'enracinement a été évaluée. Les facteurs du sol étaient fortement inter-dépendants. Les infections induites par C. fusipes diminuaient lorsque les traces d'hydromorphie apparaissaient plus profondément. Différentes espèces de Phytophthora ont été détectées dans deux des trois parcelles. Les Phytophthora étaient alors présents à la base de la majorité des chênes. La détection positive des Phytophthora était fortement liée à la saison de piégeage. L'état sanitaire des chênes diminuait avec la sévérité des infections induites par C. fusipes et la profondeur d'apparition des traces d'hydromorphie. Au contraire, aucun lien n'a pu être mis en évidence entre l'état sanitaire des chênes et la présence du Phytophthora dans le sol.

Quercus / Collybia fusipes / pourridié / Phytophthora sp. / dépérissement du chêne

\section{INTRODUCTION}

European oak forests have undergone several dieback episodes in the two last centuries [9]. Oak decline is a multi-factorial phenomenon that has been attributed to many different causes and often involves a succession of several biotic and abiotic factors. Pedunculate oak (Quercus robur L.), appears to be the main species suffering from decline [23]. In particular, decline of pedunculate oaks growing in poor soil conditions often with limits to vertical root growth (gravel layer or ground water table) has often been mentioned in association with attacks of fungal parasites $[2,9,15,17]$. Q. robur is indeed a species well resistant to temporary waterlogging but susceptible to climatic stress such as drought and requiring soils rich in nutrients [3]. Pedunculate oak was often introduced in sites beyond its optimal ecological range which is probably an underlying cause of many decline cases [3,23].
Around 1980, it was reported that the basidiomycete Collybia fusipes (Bull. Ex Fr.) Quél. was involved in the decline of pedunculate oak, in particular in soils not submitted to waterlogging $[11,13,15]$. This parasite is common in the French oak forests $[24,30]$ and often has a scattered distribution within a forest. It is a slow primary parasite that produces typical orange lesions on large roots and causes a drastic destruction of the root system [25]. In some types of soil, severe root infection was associated with a deterioration of crown health status in particular in coarse textured soils [26].

Recently, other studies have reported that Phytophthora species may be involved in pedunculate oak decline [18]. In Bavaria, Jung et al. [19] reported a positive correlation between presence of $P$. quercina sp. nov. and oak crown condition. Numerous Phytophthora species can also be found in French oak forest soils $[10,16]$. Phytophthora spp. have a multi-cyclic development with rapid increase of inoculum due

\footnotetext{
* Corresponding author: marcais@ nancy.inra.fr
} 
Table I. Description of the study sites.

\begin{tabular}{lcccc}
\hline $\begin{array}{l}\text { Site } \\
\text { (area in France) }\end{array}$ & Oak species & $\begin{array}{c}\text { No. trees assessed for } \\
\text { C. fusipes infection } \\
\text { (No. of declining) }\end{array}$ & $\begin{array}{c}\text { Soil texture } \\
\text { Parental } \\
\text { material }\end{array}$ & $\begin{array}{c}\text { Soil } \\
\mathrm{pH}\end{array}$ \\
\hline $\begin{array}{l}\text { Ainvelle } \\
\text { (Haute-Saône) }\end{array}$ & Q. robur & $60(20)$ & Clayey sandy loam & Gravel \\
$\begin{array}{l}\text { Mersuay } \\
\text { (Haute-Saône) }\end{array}$ & Q. robur & Sandy clayey loam & Gravel \\
$\begin{array}{l}\text { Filain } \\
\text { (Haute-Saône) }\end{array}$ & $\begin{array}{l}\text { Q. robur } \\
\text { (10\% } \text { Q. petraea }\end{array}$ & $50(22)$ & Clay & Limestone \\
\hline
\end{tabular}

to the production of sporangia and motile zoospores from infected roots. The increase of inoculum may be short in time but could potentially have lasting influence on tree health. Depending on the species, Phytophthora can cause death of fine roots, lesions on taproots, collar or stem $[12,18]$. $P$. cinnamomi, cause of the ink disease on sweet chestnut and of a canker on oak is probably the most documented species in Europe. Conversely, the ecology of other Phytophthora species and their role in decline is not well understood. For example, species widespread in oak forests, such as $P$. quercina and $P$. europaea, have just been recently described [20, 21]. Despite the presence of Phytophthora species in a wide range of ecological situations, they appear to be infrequent in acidic soils with a coarse texture $[10,19]$.

This work aimed at clarifying the relationships between different factors such as soil conditions (presence of gravel layer impeding rooting, severity of waterlogging), root parasites (C. fusipes or Phytophthora) and crown health status of $Q$. robur at three sites were $C$. fusipes was already known to be frequent. More precisely, we tried to identify which soil factors were related to the distribution of $C$. fusipes and Phytophthora within a stand and which factors (biotic or abiotic) were the better correlated with crown deterioration.

\section{MATERIALS AND METHODS}

\subsection{Study sites}

Trees were sampled in three plots of north-eastern France where C. fusipes was frequent: Ainvelle, Mersuay and Filain. In Ainvelle and Mersuay, located on alluvial forests, the soil consisted in a coarse textured layer of varying thickness covering a layer of gravel. Few roots over $1 \mathrm{~cm}$ in diameter extended into this gravel layer which represented a strong constraint on tree rooting. In those two plots, the stands were old coppices with standards, with $Q$. robur in the overstory and hornbeam (Carpinus betulus L.) in the understory. The topography of the two plots was flat. Filain was a 100 -year-old plantation of pedunculate oaks mixed with about $10 \%$ of sessile oak $(Q$. petraea), established on former agricultural land on a calcareous plateau, along a 7\% slope. The soil was of a clay texture and presented no limitation to vertical root growth (Tab. I). Within the soil of each of the three plots, waterlogging was very heterogeneous.

\subsection{Tree sampling}

At each study site, between 55 and 60 oaks were selected on the basis of their crown appearance. The crown health status was rated on a 0-3 scale adapted from Nageleisen [27] and from the European system based on defoliation percentage [1]: (0) crown healthy and opaque with dense secondary ramifications, defoliation percentage under 10\%; (1) crown moderately healthy, with dead twigs present and/or gaps present in the canopy, corresponding to a defoliation percentage between 10 and 25\%; (2) crown moderately declining, with the gaps in the canopy coalescing at the periphery of the crown and forming openings towards the outside in the upper part of the crown. The skeleton of large limbs is fully visible. Defoliation percentage between 25 and 50\%; (3) crown severely declining, with large dead limbs in the upper part of the crown and/or loss of more than half of fine branches; defoliation greater than $50 \%$. Only $Q$. robur were selected to obtain one third of healthy oaks rated as 0 or 1 , one third moderately declining oaks rated as 2 and one third declining oaks rated as 3 (Tab. I). Most selected oaks were dominant trees. Oak species was determined from leaf morphology by observing the foliage with binoculars.

\subsection{Site and tree investigation}

A core of soil was extracted at the base of each tree with an earth auger. Soils of the three plots were described for depth to first signs of waterlogging (first reddish traces of insoluble oxidized iron and / or discoloration indicating iron depletion). At Ainvelle and Mersuay, the depth of a gravel layer sufficient to limit vertical growth of roots was recorded. At Filain, within a sub sample of 28 oaks, fine root characteristics were studied. These trees were selected according to their crown health status. Seventeen were moderately declining (rated as 2) and 11 were healthy (rated as 0 or 1 ). Small oak roots were collected in the soil below selected trees in 4 blocks of $30 \mathrm{~cm} \times 30 \mathrm{~cm} \times$ $30 \mathrm{~cm}$ and were sorted visually according to morphological features. Medium sized roots ('mother roots', 2-5 $\mathrm{mm}$ in diameter) were selected and measured in length. Living fine roots (less than $2 \mathrm{~mm}$ in diameter) present along mother roots were counted. Roots were dried and weighed. Quantification parameters were (i) abundance of mother roots (length per volume of soil), (ii) abundance of fine roots (number per length of mother roots), and (iii) dry weight of fine roots per dry weight of mother roots.

\subsection{Assessment of root damage induced by $C$. fusipes}

In Ainvelle, Mersuay and Filain, root systems of 60, 60 and 55 oaks respectively were studied for $C$. fusipes infection as described by Marçais et al. [25]. Briefly, the root collar and major roots were partially excavated to a depth of about $20-30 \mathrm{~cm}$ and a distance of about $80-100 \mathrm{~cm}$ from the trunk base. Lesions caused by $C$. fusipes were detected as patches of infected bark that were orange in colour with small white fans of mycelium scattered within the necrotic tissues. In pedunculate oaks, hypertrophy of the bark is usually observed as infected bark is thickened up to $3-4 \mathrm{~cm}$. Previous work showed that $C$. fusipes is consistently isolated from such lesions on oak roots $[15,25,26]$. The infection status of each major root was assessed within the following four classes: (0) no necrosis detected; 
Table II. Number of trees investigated for Phytophthora presence in the soil at their base, on each plot, and at each sampling date.

\begin{tabular}{|c|c|c|c|c|c|c|c|c|}
\hline & \multirow[b]{2}{*}{$\begin{array}{l}\text { No. of trees } \\
\text { investigated }\end{array}$} & \multicolumn{7}{|c|}{ Date of sampling } \\
\hline & & $\begin{array}{l}18 \text { May } 1999 \\
\text { (spring) }\end{array}$ & $\begin{array}{l}8 \text { Feb. } 2000 \\
\text { (winter) }\end{array}$ & $\begin{array}{l}24 \text { Feb. } 2000 \\
\text { (winter) }\end{array}$ & $\begin{array}{l}15 \text { Mar. } 2000 \\
\text { (winter) }\end{array}$ & $\begin{array}{l}5 \text { Apr. } 2000 \\
\text { (winter) }\end{array}$ & $\begin{array}{l}14 \text { Jun. } 2000 \\
\text { (spring) }\end{array}$ & $\begin{array}{l}25 \text { Jul. } 2000 \\
\text { (summer) }\end{array}$ \\
\hline Ainvelle & 15 & & & $10^{\mathrm{a}}$ & & 10 & & \\
\hline Mersuay & 47 & $8^{b}$ & $10^{c}$ & & $20(10)^{\mathrm{d}}$ & & $20(10)$ & $20(10)$ \\
\hline Filain & 39 & 8 & & & & $20(11)$ & $20(11)$ & $21(11)$ \\
\hline
\end{tabular}

a Including 5 trees sampled again the 5 Apr. 2000 .

$\mathrm{b}$ Including 1 tree sampled again in 8 Feb. 2000, 2 on 14 Jun. 2000, on 25 Jul. 2000 and 2 on 15 Mar. 2000, 14 Jun. 2000 and 25 Jul. 2000.

${ }^{c}$ Including 1 tree sampled again in Mar. 2000, 1 on 14 Jun. 2000, and 3 on 25 Jul. 2000.

${ }^{d}$ In brackets: number of trees sampled repetitively in winter, spring and summer.

(1) superficial necrosis present, but covering less than half of the root circumference (penetration of $C$. fusipes in the bark of no more than 1-2 mm); (2) necrosis covering one side of the root entirely with a penetration of the parasite in the bark usually more than $2-5 \mathrm{~mm}$; (3) C. fusipes infection over the entire root circumference but root still alive (penetration of the parasite in the bark of usually more than 4-5 mm); (4) root dead with decayed wood. Root diameter was measured at about $10 \mathrm{~cm}$ from the trunk base. The root infection index of a tree was computed as: $\Sigma$ (root diameter $\times$ root rating) $/ \Sigma$ (root diameter). This index therefore takes value from 0 to 4 .

\subsection{Assessment of Phytophthora presence in the soil}

In each stand, a sub-sample of oaks was selected to assess the presence of Phytophthora in the soil at the tree base. These trees were representative of the different crown conditions from healthy to declining. Soil sampling was carried out from May 1999 through 2000. Some of the trees were repeatedly sampled at different seasons (winter, spring and summer, see Tab. II).

Methods of soil collection and of Phytophthora isolation were those described by Hansen and Delatour [16], adapted from Jung et al. [18]. For each tree, soil was collected in four opposite directions at a distance of about $80-100 \mathrm{~cm}$ from the stem base. The litter was scraped away and soil was collected to a depth of about $20 \mathrm{~cm}$; the four samples from a tree were mixed together. Baiting was performed under standard laboratory conditions (about $20^{\circ} \mathrm{C}$, diffuse light). About $200 \mathrm{~mL}$ of each soil sample were then flooded with deionized water to a depth of $2 \mathrm{~cm}$ (about $500 \mathrm{~mL}$ ) and baited by floating oak leaflets on the surface (6-10 baits). Baits were removed after 3 days and blotted dry; necrotic parts of oak leaflets were transferred to selective agar medium (BARPBHy; corn meal agar Difco with $200 \mathrm{mg}$ ampicillin, $10 \mathrm{mg}$ rifampicin, $10 \mathrm{mg}$ pimaricin, $15 \mathrm{mg}$ benomyl, and $50 \mathrm{mg}$ hymexasol per liter). Plates were examined daily and possible Phytophthora colonies were transferred to three different media for identification: corn meal agar amended with $B$-sitosterol, potato dextrose agar, and $200 \mathrm{~mL}$ Joker, $(\mathrm{V}-8$ like clarified multivitamin juice) amended with $7 \mathrm{~g}$ per $500 \mathrm{~mL} \mathrm{CaCO} 3,20 \mathrm{~g}$ agar and $800 \mathrm{~mL}$ deionized water.

Isolates were identified according to growth pattern, and morphology of colonies, sporangia, and oogonia when present, using previously identified species as a reference, and information from Erwin and Ribeiro [14].

\subsection{Statistical analysis}

In Mersuay, because of severe Armillaria infection, one tree was removed from further analysis.

To study the relationship between soil characteristics and C. fusipes infection severity, the root infection index was log trans- formed and subjected to an analysis of variance using the procedure "glm" of SAS [31]. At first, for each plot, each independent factor was introduced alone in the model in order to assess the statistical link of each factor independently from the others. Thereafter, independent factors were all introduced together in the model to study the colinearity between the different factors.

The relationship between frequency of Phytophthora species isolation and soil factors was analysed by generalised linear analysis, using the procedure "genmod" of SAS. A binomial distribution of the data was assumed and the logistic link function was used. The model validity was checked using the deviance/degree of freedom ratio, by plotting deviance residuals against the linear predictor and with a half-normal plot [8]. Because the season of baiting appeared to be an important factor for Phytophthora isolation success, the effect of soil factor was tested by taking into account only trees sampled in summer or spring or sampled in winter but with a positive baiting for $P$. quercina. For $P$. europaea, only trees sampled in winter or spring or sampled in summer with a successful baiting, were used in the analysis. For $P$. syringae-like ${ }^{1}$, only trees sampled in winter or sampled in summer and spring but with a successful baiting were included in the analysis.

The statistical relationship between the presence of Phytophthora in soil and the damages induced by $C$. fusipes was assessed for each species with a Student $t$ test comparing the mean $C$. fusipes root infection index when the Phytophthora species was present, with index when absent. Data from Mersuay and Filain were grouped. To take into account the strong influence of season on Phytophthora baiting success, the analysis was carried out in the same way as for analysis of relationship between Phytophthora species isolation and soil factors.

The relationship of crown health status of the trees with soil characteristics or root infection index induced by $C$. fusipes or presence of Phytophthora at the base of tree, was analysed by generalised linear analysis, using the procedure "genmod" of SAS. A multinomial distribution of the data was assumed and the cumulative logit link function was used. Like in the variance analysis, each independent factor was first introduced alone in the model and thereafter all independent factors were introduced together. Seasonal influence was taken into account in the same way as for analysis of the relationship between Phytophthora species isolation and soil factors.

${ }^{1}$ All the isolates noted here as Phytophthora syringae-like are morphologically similar to $P$. syringae. Two isolates belonging to this morphological group, 'C32b' (from Amance 31-15), and 'Edr6' (from Mersuay), were examined by Winton and Hansen [34]. Based on the ITS DNA sequences, they were quoted as unidentified species. In this group, isolates are homothallic (oogonia: c.a. $30-40 \mu$ in diam.), paragynous antheridia, semi-papillate sporangia (ovoid-subpyriforme; c.a. 50-60 × 30-45 $\mu$, ratio c.a. 1.4-1.6), optimal growth temperature below $23{ }^{\circ} \mathrm{C}$, stellate pattern and radial growth rate c.a. $3-4 \mathrm{~mm}$ per day at $20^{\circ} \mathrm{C}$ on CMA. 
Table III. Analysis of variance of the relationships between depth of waterlogging (iron traces deposition or depletion) and depth of gravel layer with the $C$. fusipes root infection index.

\begin{tabular}{|c|c|c|c|c|c|c|c|c|c|c|c|c|}
\hline \multirow{2}{*}{$\begin{array}{l}\text { Plot } \\
\text { Source }\end{array}$} & \multicolumn{4}{|c|}{ Ainvelle } & \multicolumn{4}{|c|}{ Mersuay } & \multicolumn{4}{|c|}{ Filain } \\
\hline & Df & $\begin{array}{l}\text { Mean } \\
\text { square }\end{array}$ & $\begin{array}{c}\mathrm{F} \\
\text { square }\end{array}$ & $P$ & $\overline{D f}$ & $\begin{array}{l}\text { Mean } \\
\text { square }\end{array}$ & $\begin{array}{c}\mathrm{F} \\
\text { square }\end{array}$ & $\begin{array}{c}P \\
\text { value }\end{array}$ & $\overline{\mathrm{Df}}$ & $\begin{array}{l}\text { Mean } \\
\text { square }\end{array}$ & $\begin{array}{c}\mathrm{F} \\
\text { square }\end{array}$ & $P$ \\
\hline Model & 2 & 10.48 & 17.15 & $<0.001$ & 2 & 8.79 & 14.28 & $<0.001$ & 1 & 8.55 & 10.8 & 0.002 \\
\hline Error & 57 & 0.61 & - & - & 56 & 0.62 & - & - & 53 & 0.79 & - & - \\
\hline Waterlogging depth & 1 & 17.88 & 29.18 & $<0.001$ & 1 & 14.85 & 24.13 & $<0.001$ & 1 & 8.55 & 10.8 & 0.002 \\
\hline Gravel depth & 1 & 2.03 & 3.32 & 0.074 & 1 & 0.41 & 0.66 & 0.418 & - & - & - & - \\
\hline
\end{tabular}

Note: the mean squares are of type 3 .

In Filain, the relationship between tree crown health status and fine roots characteristics was analysed using a Student $t$ test comparing the mean of each parameter describing fine root status when trees where healthy or when trees where moderately declining.

\section{RESULTS}

\subsection{Relationships between soil factors}

In Mersuay, signs of waterlogging appeared deeper in the soil when the gravel layer was closer under the soil surface whereas in Ainvelle these two parameters were not linked (Pearson correlation coefficients respectively of -0.53 and 0.08 , probabilities respectively lower than 0.001 and of 0.540 ). In Filain, the depth to first signs of waterlogging was the only soil parameter evaluated.

\subsection{Relationship between soil factors and root infection induced by $C$. fusipes}

In Ainvelle, Filain and Mersuay, 53\%, 63\% and 59\% of oak trees, respectively, were infected by C. fusipes, while $20 \%, 9 \%$ and $27 \%$ of trees, respectively, were severely damaged with a root infection index above 2 . Only one oak in Mersuay showed most of the roots which did not express the typical orange colour of $C$. fusipes infection, but rather infections that looked like Armillaria infections with brown lesions and mycelial fans at the cambium. Armillaria was also detected on three other oaks in Mersuay, three oaks in Filain and two in Ainvelle. In these cases Armillaria was present on a minority of roots, inducing superficial lesions, the root infection index was thus computed by taking into account these infected roots.

In the three plots, Ainvelle, Mersuay and Filain, there was a significant relationship between the $C$. fusipes root infection index and the depth at which the first signs of waterlogging occurred in the soil. (Fisher's F respectively of 28.66, 28.05, 10.80 ; df of $1 ; P$ values all lower than 0.002 ). Indeed, the severity of infection increased in the 3 stands when waterlogging signs appeared deeper in the soil (Fig. 1).

In Mersuay, the root infection index tended to decrease with the depth at which the gravel layer appeared in the soil, whereas in Ainvelle the opposite tendency was observed (Fisher's F of respectively 3.15 and 3.01, df of $1, P$ values of respectively 0.081 and 0.088 ). Indeed, in Mersuay the root infection index decreased with the gravel layer depth (from $1.6 \pm 0.2$ for a gravel layer depth of less than $70 \mathrm{~cm}$ to $0.7 \pm$

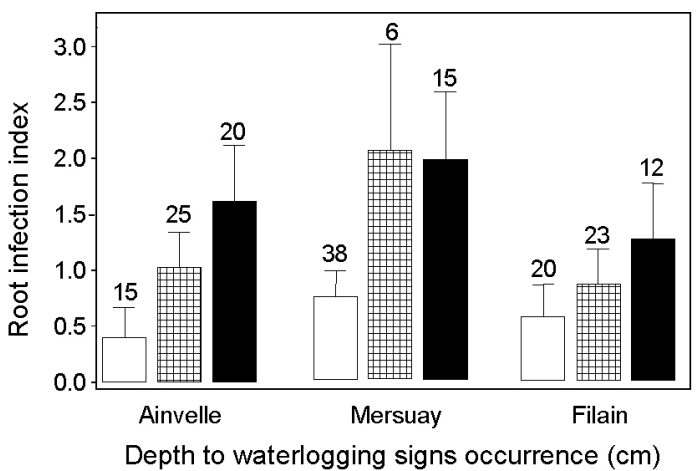

Figure 1. Mean $C$. fusipes root infection index in the three studied plots according to different categories of waterlogging depth, evaluated as the depth to first iron traces deposition or depletion in the soil: ( $\square$ ) 0-40 cm; (曲) 41-60 cm; ( $>60 \mathrm{~cm}$. The bars represent the confidential interval of the mean. The number of trees in each category is given above the bar.

0.2 for a gravel layer depth deeper than $90 \mathrm{~cm}$ ) whereas it increased in Ainvelle (from $0.6 \pm 0.2$ for a gravel layer depth of less than $70 \mathrm{~cm}$ to $1.3 \pm 0.3$ for a gravel layer depth deeper than $90 \mathrm{~cm}$ ).

In Mersuay and Ainvelle, there was a strong colinearity between both soil factors studied. When these soil factors were entered together in the variance analysis model, only the depth to waterlogging occurrence remained significantly linked to the root infection index (Tab. III).

\subsection{Relationship between soil factors, season of baiting and Phytophthora isolation}

In Ainvelle, despite soil baiting carried out at two different dates (Tab. II) we did not find evidence of Phytophthora in the soil. Conversely, in Mersuay and Filain Phytophthora was present at the base of $70 \%$ and $87 \%$ respectively of trees investigated. In these plots, several Phytophthora species were detected: $P$. quercina was isolated at the base of $50 \%$ of oaks investigated, $P$. syringae-like and $P$. europaea were present at the base of $27 \%$ and $26 \%$ respectively of oaks investigated. $P$. cambivora, P. citricola, P. gonapodyides were occasionally isolated but at too low frequency to allow any further analysis. The probability of isolating a Phytophthora species at the base of trees, increased with the number of sampling dates (from $68 \%$ when baiting was carried out at one date to $95 \%$ for trees when baiting was done on three dates or more). 
Table IV. Logistic regression analysis of the relationships between severity of the waterlogging (depth of iron traces deposition or depletion) and depth of the gravel layer with frequency of Phytophthora positive isolations.

\begin{tabular}{|c|c|c|c|c|c|c|c|c|c|c|}
\hline \multicolumn{2}{|c|}{ Phytophthora species } & \multicolumn{3}{|c|}{ P. quercina } & \multicolumn{3}{|c|}{ P. syringae-like } & \multicolumn{3}{|c|}{ P. europaea } \\
\hline Plot & Source & Df & Chi-square & Pr $>$ Chisq & Df & Chi-square & Pr $>$ Chisq & Df & Chi-square & Pr $>$ Chisq \\
\hline Filain & $\begin{array}{c}\text { Waterlogging } \\
\text { depth }\end{array}$ & 1 & 1.13 & 0.287 & 1 & 0.15 & 0.699 & 1 & 1.62 & 0.203 \\
\hline \multirow[t]{2}{*}{ Mersuay } & $\begin{array}{c}\text { Waterlogging } \\
\text { depth }\end{array}$ & 1 & 4.52 & 0.034 & 1 & 1.57 & 0.210 & 1 & 0.77 & 0.381 \\
\hline & Gravel depth & 1 & 2.94 & 0.086 & 1 & 0.71 & 0.398 & 1 & 4.47 & 0.035 \\
\hline
\end{tabular}

Note: the Chi-squares are of type 1 .
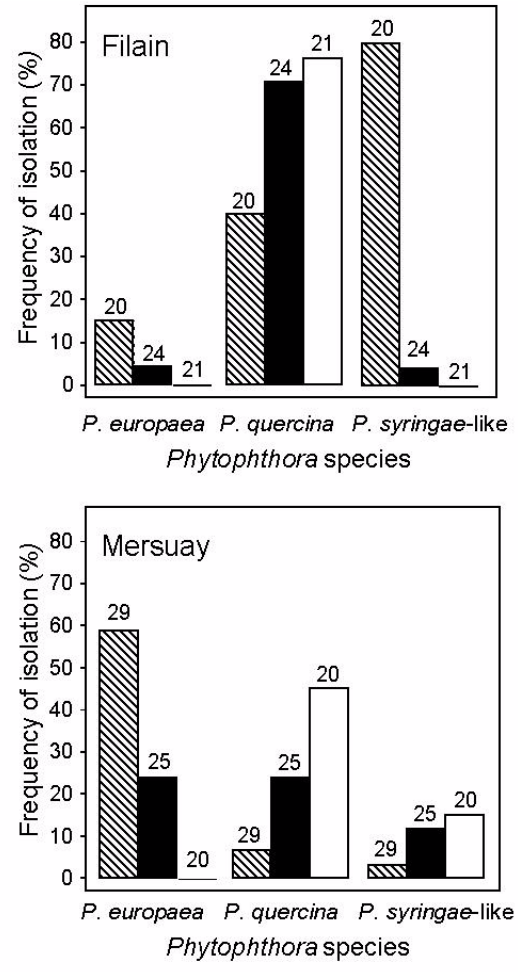

Figure 2. Effect of the season on the frequency of Phytophthora species isolation from soil at Mersuay and Filain. (winter: Feb. to Apr.; ( Spring: May-June; ( $\square$ ) Summer: July. The number of Phytophthora baiting carried out is given above the bars.

The frequency of positive isolation of $P$. europaea and $P$. quercina was significantly influenced by the season at which the baiting was carried out (in Filain, likelihood $\mathrm{X}^{2}$ respectively of: 4.83 and 6.66 , df of 2, probabilities respectively of 0.089 and 0.036 ; in Mersuay, likelihood $\mathrm{X}^{2}$ respectively of 6.66 and 10.13 , df of 2, probabilities respectively of 0.036 and 0.006). In Mersuay and Filain, the frequency of $P$. europaea isolation from soil was high in winter (from February to April) and very low in summer (Fig. 2). In these two plots, the frequency of $P$. quercina isolation was high in summer (July) and low in winter (Fig. 2). The results for P. syringae-like isolation were inconsistent, the frequency being significantly higher in winter at Filain but not in summer at Mersuay (like- lihood $\mathrm{X}^{2}$ respectively of: 46.37 and 2.38 , df of 2 , probabilities respectively less then 0.001 and of 0.305 ; Fig. 2).

In Filain and Mersuay, after the effect of season of baiting was taken into account, the frequency of positive Phytophthora isolation from soil did not appear to be linked with the depth to occurrence of waterlogging signs in the soil (Tab. IV). Nevertheless, in Mersuay there was a tendency to isolate $P$. quercina more frequently when the waterlogging signs appeared deeper in the soil. Indeed, the frequency of positive baiting increased from $37 \%$ when waterlogging signs appeared above $40 \mathrm{~cm}$ to $67 \%$ when they appeared deeper than $60 \mathrm{~cm}$. In Mersuay, the frequency of positive baiting of $P$. quercina and $P$. syringae-like was not linked with the depth of occurrence of the gravel layer in the soil (Tab. IV), whereas positive isolations of $P$. europaea decreased significantly with the depth of occurrence of the gravel layer (from 60\% when the gravel layer appears above $70 \mathrm{~cm}$ depth, to $13 \%$ when it appears below $90 \mathrm{~cm}$ ).

\subsection{Relationships between Phytophthora presence and $C$. fusipes infection severity}

$C$. fusipes root infection index was linked neither with the presence of $P$. quercina in soil, nor with the presence of $P$. syringae-like or of $P$. europaea ( $t$ values respectively of $-0.10,-0.18$ and -1.70 , probabilities higher than 0.14 ).

\subsection{Relationship between $Q$. robur crown health status, soil factors, damages induced by $C$. fusipes and presence of Phytophthora}

In Ainvelle and Mersuay the crown health status was worse when waterlogging signs appeared deeper in the soil (Likelihood $\mathrm{X}^{2}$ respectively of: 10.61 and 14.10 , df of 1 , probabilities both lower than 0.001 ; Fig. 3). The same tendency but not significant was observed in Filain (Likelihood $\mathrm{X}^{2}$ of 3.05, df of 1, probability of 0.081 ; Fig. 3 ). The relationship between the depth to the gravel layer and oak crown status was inconsistent. Indeed in Mersuay, the crown health status became worse when the gravel layer appeared closer to the soil surface whereas there was no relationship between tree crown status and gravel layer depth in Ainvelle (Likelihood $\mathrm{X}^{2}$ respectively of: 4.60 and 1.52, df of 1, probabilities respectively of 0.032 and 0.218; Fig. 4). In Ainvelle, Mersuay and Filain, the severity of infection by $C$. fusipes was very significantly linked with the crown health status of oaks (Likelihood $\mathrm{X}^{2}$ respectively 
Table V. Logistic regression analysis of the relationship between the crown health status of oaks and the $C$. fusipes root infection index, the depth of waterlogging signs (traces of iron deposition or depletion) and the depth of gravel layer occurrence.

\begin{tabular}{|c|c|c|c|c|c|c|c|c|c|}
\hline Plot & & Ainvell & & & Mersuay & & & Filain & \\
\hline Source & Df & Chi-square & Pr $>$ Chisq & Df & Chi-square & Pr $>$ Chisq & Df & Chi-square & $\operatorname{Pr}>$ Chisq \\
\hline Root infection index & 1 & 6.51 & 0.011 & 1 & 3.26 & 0.071 & 1 & 8.71 & 0.003 \\
\hline Waterlogging depth & 1 & 1.51 & 0.219 & 1 & 2.29 & 0.130 & 1 & 0.40 & 0.525 \\
\hline Gravel depth & 1 & 0.47 & 0.491 & 1 & 0.28 & 0.594 & - & - & - \\
\hline
\end{tabular}

Note: the Chi-squares are of type 3.

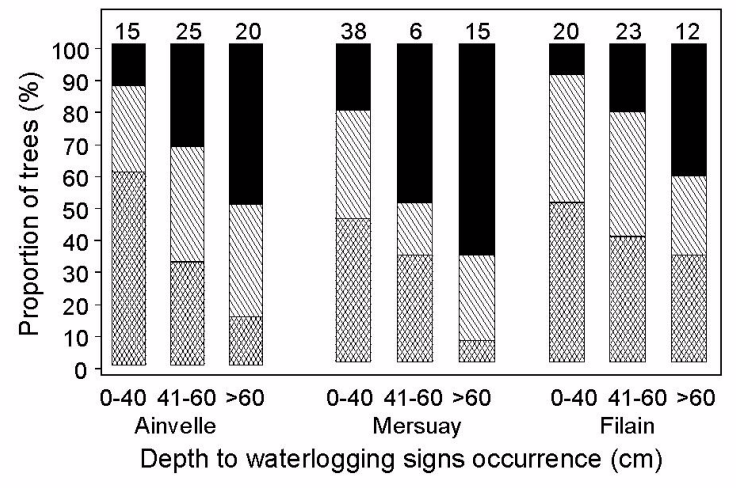

Figure 3. Relationship between depth to waterlogging signs occurrence in the soil (traces of iron deposition or depletion) and crown health status of oak trees in the three plots. ( $X \times x \times x)$ crown healthy; (IIIIV) crown moderately declining; () crown heavily declining. Depth to waterlogging signs was categorised in three classes. The number of trees in each category is given above the bars.

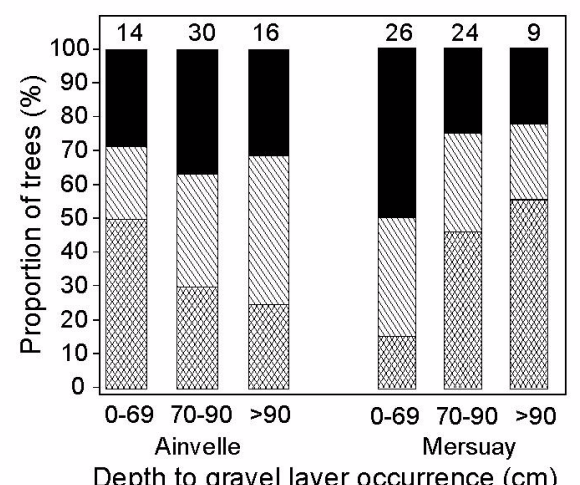

Figure 4. Relationship between crown health status of oak trees and depth to gravel layer occurrence in the soil in Ainvelle and Mersuay. ( $\triangle \triangle \triangle \triangle X X)$ crown healthy; (\$IIIIV) crown moderately declining; crown heavily declining. Depth to gravel layer occurrence was categorised in three classes. The number of trees in each category is given above the bars.

of: $16.88,13.18$ and 11.35 , df of 1 , probabilities lower than $0.001)$. The crown health status of oak trees was worse when the severity of infection by C. fusipes increased (Fig. 5). The majority of oak trees rated as severely infected by $C$. fusipes were rated as moderately or heavily declining trees ( 31 out of 33 in the three plots). There was a strong colinearity between

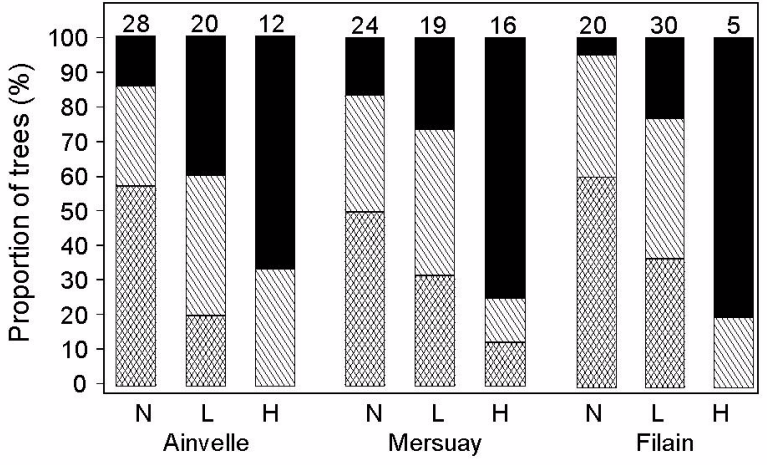

Severity of $C$. fusipes root infection

Figure 5. Relationship between root infection by Collybia fusipes and crown health status of oak trees. Infection severity was categorised: $\mathrm{N}$ corresponding to undamaged tree with a root infection index of $0-0.3$, $\mathrm{L}$ corresponding to tree lightly damaged with a root infection index of 0.3 to 2 and $\mathrm{H}$ to tree heavily damaged with a root infection index of more than 2. ( $\$ \times \times \times \times)$ crown healthy; (IIITIV) crown moderately declining; ( ) crown heavily declining. The number of trees in each category is given above the bars.

the severity of waterlogging and of C.fusipes infection. Indeed, when all soil characteristics and root infection index were entered together in the model, only the root infection index remained significantly linked with crown status in Ainvelle and Filain, and almost significantly linked with crown health status in Mersuay (Tab. V).

There was no relationship between the presence of Phytophthora, whatever the species (P. europaea, P. quercina, $P$. syringae-like ), and the tree crown health status (likelihood $\mathrm{X}^{2}$ respectively of $0.31,0.32,0.13$, df of 1 , probabilities respectively of: $0.577,0.570$ and 0.721 ; Fig. 6 ).

In the sub-sample of oaks investigated for their root characteristics in Filain, there was no statistical relationship between the crown health status of trees, rated as healthy or moderately declining and the length of mother roots per volume of soil ( $t$ value of 0.77 and probability of 0.447 ), the number of fine roots per length of mother roots ( $t$ value of -1.35 and probability of 0.189 ) or the dry weight of fine roots per dry weight of mother roots ( $t$ value of 1.19 and probability of 0.854 ).

\section{DISCUSSION}

In the three studied plots, there was a strong colinearity between soil factors and root infection induced by $C$. fusipes. 


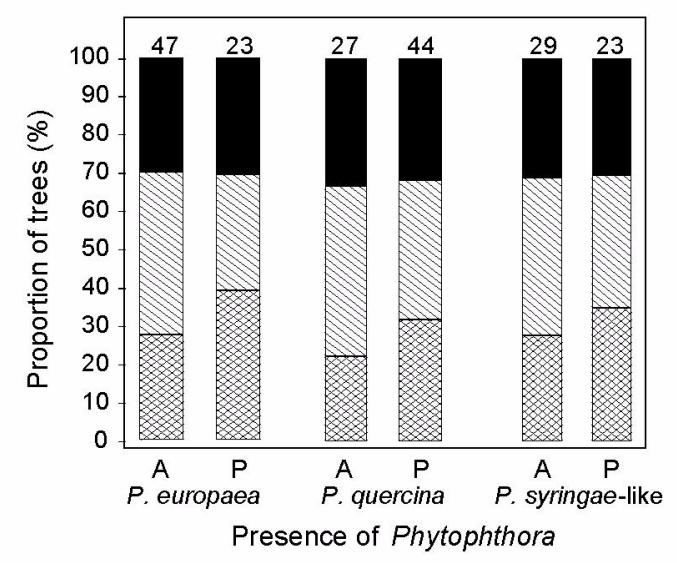

Figure 6. Relationship between absence (A) or presence (P) of Phytophthora in soil, and crown health status of oak trees. Baitings of Phytophthora taken into account were those carried out during the seasons where the higher level of positive isolation was observed and those positively isolated in other seasons. Data from Filain and Mersuay were grouped. ( $\mathbb{X \times X \times X ] )}$ crown healthy; (\$TITIV) crown moderately declining; ( $)$ crown heavily declining. The number of trees in each category is given above the bars.

This parasite induced more severe damages where soil was less frequently waterlogged. By contrast, there was no relationship between $C$. fusipes infection and presence of Phytophthora and the relationship between $C$. fusipes infection and depth at which a gravel layer impeding rooting appeared was inconsistent. $C$. fusipes was already reported to be more frequent in dry soil conditions and to induce fewer root infection in waterlogged soils $[11,28,30]$. Likewise, in a field inoculation $C$. fusipes inoculum survival was strongly reduced in waterlogged conditions and increased in coarse textured soils [6]. Effect of waterlogging could be related to the availability in oxygen as $C$. fusipes in vitro growth appears to be strongly inhibited by low aeration conditions [7]. Several other root rot inducing fungi were shown to have a higher incidence in dry soil conditions, like Armillaria spp. or Inonotus tomentosus on spruce [4, 33]. Kuhlman [22] also observed that root segments of loblolly pine were more decayed by Heterobasidion annosum when they were buried in dry soil. The frequency of positive Phytophthora isolation from soil was strongly influenced by the season of baiting at least for P. quercina and $P$. europaea. This seasonal influence partly explains why repeated sampling on the same sites often yield inconsistent responses with different Phytophthora species present in the different samplings [10]. Thus, evaluation of the Phytophthora spp. population in a site would require to take into account the fluctuation of the different species over time in the soil. This difference in seasonal activity of P. quercina and $P$. europaea points out strong differences in the infection biology. Indeed, Brasier and Hansen [5] suggested that seasonality of moisture in relation to temperature had certainly influenced the strategies of survival and the biology of Phytophthora species. There was not clear relationship between the distribution of Phytophthora in the plots and the severity of soil waterlogging. This is quite surprising as Phytophthora spp. are known to be favoured in wet fine textured soils $[5,19]$ and as $P$. quercina and $P$. europaea were shown to be preferentially distributed in low point prone to waterlogging [16]. In our two plots, Phytophthora appeared to be distributed throughout the stands; when baiting was carried out at different seasons, Phytophthora could be detected on virtually all trees. For Mersuay a possible explanation could be that the periodic flooding distributes Phytophthora all over the plot. However, this can not explain the situation of Filain where trees were distributed along a strong slope. Phytophthora spp. were absent in the plot of Ainvelle which has the most acidic soil of the 3 studied plots. This is likely to be related to the soil texture and $\mathrm{pH}$, as Jung et al. [19] showed that Phytophthora spp. were absents from sandy acidic soils.

In the three studied plots, the crown health status was tightly correlated with both the severity of damage induced by C. fusipes and the severity of waterlogging and to a lesser degree with the depth of occurrence of a gravel layer impeding rooting. These factors were strongly correlated. By contrast, an other studied factor, the presence of Phytophthora spp. did not appear to have a consistent relationship with oak crown health status. The correlation between crown health status and damages induced by $C$. fusipes confirmed that severe infections of this pathogen is linked to decline [26] and shows additionally that in the studied plots, most of the decline is linked to $C$. fusipes infection. Thereafter, it is not surprising to find several mentions of $C$. fusipes in association with different decline episodes $[11,15]$. Oak decline was often reported in the literature to occur in soils where a temporary and elevated water table occurred [23, 29]. In our case, the opposite tendency was observed, which could reflect a strong effect of infection induced by $C$. fusipes being more severe when soil was less submitted to waterlogging. Water and mineral nutrition could be an underlying cause of the decline as pedunculate oak has high needs in both [3].This could occur because oak stressed by water or nutrient shortage could be predisposed to the $C$. fusipes infection and/or trees with destroyed root systems are more prone to water stress on low water retention capacity soils. However, this hypothesis does not fit the data very well. Soils in Mersuay and Ainvelle have low water retention capacity. This is not the case in Filain where the soil is a deep clayed loam soil with no ground water table or physical layer limiting the rooting. Moreover, in Ainvelle, there is no relationship between the occurrence of a gravel layer impeding rooting and tree crown health status. Also, two of the plots, Filain and Mersuay, have soil with high nutrient content. The relation between $C$. fusipes and tree health did not appear to be affected by presence of Phytophthora. In particular, deterioration of the crown of $C$. fusipes infected oaks was similar in Mersuay, where Phytophthora are present and in Ainvelle where they are absent. No link between presence of Phytophthora and the crown health status was seen in our study in contrast to results by Jung et al. [18, 19] in German forests. This can be related to the fact that Phytophthora was widespread in the plot, and was found at the base of a majority of oaks. However, the technique used to detect Phytophthora in soil did not allow us to quantify the inoculum potential which could be better related to the crown health status. Also, an episode of root infection occurring few years before could have conceivably contributed to current crown conditions but was not detected because the Phytophthora decreased since. Likewise, Delatour 
[10] mentioned that considering together all the Phytophthora species found in European soils, no general relationship was found between their presence below individual oaks and the health of trees. Furthermore, our plots were selected on the basis of $C$. fusipes incidence and Phytophthora presence was looked at only after. Thus, those plots could represent sites not very favourable to Phytophthora development. The crown health status was also not correlated with fine roots characteristics because it was probably too early in the decline process to detect any differences. Thomas and Hartmann [32] also showed that fine root decay was not a primary factor in the decline complex of pedunculate oak.

Such a study underlined correlation links between oak decline and biotic or abiotic factors but it remains difficult to explain the dynamic of the phenomenon as no causality link can be derived from correlations. However, in this study, different factors possibly involved in decline of oaks, such as root pathogens and soil factors were evident. It is worth noting that all these biotic and abiotic factors are inter-dependant and that oak decline obviously results from their combined effect.

Acknowledgements: The authors wish to thank O. Caël, J. Demaison, G. Maréchal and F. Tabary for their technical assistance and E. Hansen for reviewing the manuscript. This work was supported by the European Commission, Project Fair 5-CT97-3926, "Long term dynamics of oak ecosystems: assessment of the role of root pathogens and environmental constraints as interacting decline inducing factors" (PATHOAK).

\section{REFERENCES}

[1] Anonymous, Manual on methods and criteria for harmonised sampling, assessment, monitoring and analysis of the effects of air pollution on forests, United Nation Economic Commission for Europe, Internat. Co-operative Program, 4th edition, 1997.

[2] Becker M., Levy G., Le dépérissement du chêne en forêt de Tronçais. Les causes écologiques, Ann. Sci. For. 39 (1982) 439-444.

[3] Becker M., Lévy G., Le point sur l'écologie comparée du chêne sessile et du chêne pédonculé, Rev. For. Fr. 42 (1990) 148-154.

[4] Bernier D., Lewis K.J., Site and soil characteristics related to the incidence of Inonotus tomentosus, For. Ecol. Manage. 120 (1999) 131-142.

[5] Brasier C.M., Hansen E., Evolutionary biology of Phytophthora, Part II: Phylogeny, Speciation and Population Structure, Annu. Rev. Phytopathol. 30 (1992) 173-200.

[6] Camy C., Delatour D., Caël O., Marçais B., Inoculation of mature pedunculate oaks (Quercus robur) with the root rot fungus Collybia fusipes: relationships with tree vigour and soil factors, Eur. J. Plant Pathol. 109 (2003) 545-553.

[7] Camy C., Dreyer E., Delatour C., Marçais B., Responses of the root rot fungus Collybia fusipes to soil waterlogging and oxygen availability, Mycol. Res. 107 (2003) 1103-1109.

[8] Collett D., Modeling binary data, Chapman and Hall (Ed.), 1991.

[9] Delatour C., Les dépérissements des chênes en Europe, Rev. For. Fr. 35 (1983) 265-282.

[10] Delatour C., Phytophthoras and Oaks in Europe, in: Proceedings of the 2nd International meeting on Phytophthoras in Forest and Wildland Ecosystems, Perth and Albany, Australia (in press).

[11] Delatour C., Guillaumin J.J., Un pourridié méconnu : Collybia fusipes (Bull. ex Fr.) Quel, C. R. Acad. Agri. France 70 (1984) 123-126.

[12] Delatour C., Desprez-Lousteau M.L., Robin C., Pathogenicity of Phytophthora species on oaks, in: E.M. Hansen and W. Sutton (Ed), Proceedings from the First international Meeting on Phytophthoras in Forest and Wildland Ecosystems, Grants Pass, Oregon, USA, 2000, pp. 102-104.
[13] Durand P., Gelpe J., Lemoine B., Riom J., Timbal J., Le dépérissement du chêne pédonculé dans les Pyrénées-Atlantiques, Rev. For. Fr. 35 (1983) 357-368.

[14] Erwin D.C., Ribeiro O.K., Phytophthora Diseases Worldwide, APS Press, St. Paul, 1996.

[15] Guillaumin J.J., Bernard C., Delatour C., Belgrand M., Contribution à l'étude du dépérissement du chêne : pathologie racinaire en forêt de Tronçais, Ann. For. Sci. 42 (1985) 1-22.

[16] Hansen E., Delatour C., Phytophthora species in oak forest of north-east France, Ann. For. Sci. 56 (1999) 539-547.

[17] Hartmann G., Blank R., Lewark S., Eichensterben in Norddeutschland. Verbreitung, Schadbilder, Mögliche Ursachen, Forst und Holz (1989) 475-487.

[18] Jung T., Blaschke H., Neumann P., Isolation, identification and pathogenicity of Phytophthora species from declining oak stands, Eur. J. For. Path. 26 (1996) 253-272.

[19] Jung T., Blaschke H., Oswald W., Involvement of soilborne Phytophthora species in Central European oak decline and the effect of site factors on the disease, Plant Pathol. 49 (2000) 706-718.

[20] Jung T., Cooke D.E.L., Blaschke H., Duncan J.M., Oswald W., Phytophthora quercina sp. nov., causing root rot of European oaks, Mycol. Res. 103 (1999) 785-798.

[21] Jung T., Hansen E., Winton L., Osswald W., Delatour C., Three new species of Phytophthora from european oak forests, Mycol. Res. 106 (2002) 397.

[22] Kuhlman E.G., Influence of moisture on rate of decay of loblolly pine root wood by Heterobasidion annosum, Can. J. Bot. 58 (1980) 36-39.

[23] Landmann G., Becker M., Delatour C., Dreyer E., Dupouey J.-L., Oak dieback in France: historical and recent records, possible causes, current investigations, in: Rundgespräche der Kommission für Ökologie, Bd. 5 'Zustand und Gefährdung der Laubwälder', 1993, pp. 97-114.

[24] Marçais B., Caël O., Delatour C., Investigations on the distribution and impact of Collybia fusipes in oak forest, in: Delatour C., Guillaumin J.J., Lung-Escarmant B., Marçais B. (Eds.), Proceedings of 9th International Conference on Root and Butt Rots of Forest Trees, Carcans-Maubuisson France, colloques de l'INRA n ${ }^{\circ} 89$, France, 1998, pp. 215-222.

[25] Marçais B., Caël O., Delatour C., Measuring the impact of Collybia fusipes on the root system of oak trees, Ann. For. Sci. 56 (1999) 227-235

[26] Marçais B., Caël O., Delatour C., Relationship between presence of basidiomes, above-ground symptoms and root infection by Collybia fusipes in oaks, For. Path. 30 (2000) 7-17.

[27] Nageleisen L.M., Méthode d'évaluation de l'aspect du houppier (protocole DEPEFEU), Département Santé des Forêts-Echelon technique Nord-Est. Bulletin technique, 1995.

[28] Nanta M., Vellinga E.C., Atlas van Nederlandse Paddesstoelen. A.A. Balkema, Roterdam, Brookfield, 1995.

[29] Oosterbaan A., Nabuurs G.J., Relationships between oak decline and groundwater class in the Netherlands, Plant and Soil 136 (1991) 87-93.

[30] Piou D., Delatour C., Marçais B., Hosts and distribution of Collybia fusipes in France, For. Path. 32 (2002) 29-41.

[31] SAS Institute Inc., SAS/STAT User's Guide, Version 6, Fourth edition, Vol. I, Cary, 1989.

[32] Thomas F.M., Hartmann G., Soil and tree water relations in mature oak stands of northern Germany differing in the degree of decline, Ann. Sci. For. 53 (1996) 697-720.

[33] Whitney R.D., Site variation of Armillaria mellea in three Ontario conifers, in: Kile G.A. (Ed.), Proceedings of the 6th International Conference of Root and Butt Rot, International Union of Forestry Research Organizations, Melbourne, Victoria, Gympie, Queensland, Australia, 1984, pp. 122-130.

[34] Winton L.M., Hansen E.M., Molecular diagnosis of Phytophthora lateralis in trees, water, and foliage baits using multiplex polymerase chain reaction, For. Path. 31 (2001) 275-283. 